\title{
Analysis of GDF15 and IGFBP7 in Hyperemesis Gravidarum Support Causality
}

\section{Analyse von GDF-15 und IGFBP-7 bei Hyperemesis gravidarum unterstützt Kausalhypothese}

\section{(우(1) (요 $\ominus$}

\section{Authors}

Marlena S. Fejzo ${ }^{1,2}$, Peter A. Fasching ${ }^{3}$, Michael O. Schneider ${ }^{3}$, Judith Schwitulla ${ }^{3}$, Matthias W. Beckmann ${ }^{3}$, Eva Schwenke ${ }^{3}$, Kimber W. MacGibbon ${ }^{4}$, Patrick M. Mullin ${ }^{2}$

\section{Affiliations}

1 Division of Hematology-Oncology, David Geffen School of Medicine, Jonsson Comprehensive Cancer Center, University of California at Los Angeles, Los Angeles, CA, USA

2 Department of Maternal-Fetal Medicine, Keck School of Medicine, University of Southern California, Los Angeles, CA, USA

3 Department of Gynecology and Obstetrics, University Hospital Erlangen, Erlangen, Germany

4 Hyperemesis Education and Research Foundation, Damascus, OR, USA

Key words

hyperemesis gravidarum, nausea and vomiting of pregnancy, GDF15, IGFBP7, GFRAL

\section{Schlüsselwörter}

Hyperemesis gravidarum, Übelkeit und Erbrechen

in der Schwangerschaft, GDF-15, IGFBP-7, GFRAL

$$
\begin{array}{ll}
\text { received } & 18.11 .2018 \\
\text { revised } & 7.1 .2019 \\
\text { accepted } & 8.1 .2019
\end{array}
$$

Bibliography

DOI https://doi.org/10.1055/a-0830-1346

Published online 26.2.2019 | Geburtsh Frauenheilk 2019; 79 : 382-388 @ Georg Thieme Verlag KG Stuttgart · New York | ISSN 0016-5751

Correspondence

Marlena S Fejzo, PhD

5535 MRL, UCLA

675 Charles E Young Dr. South,

Los Angeles, CA 90095, USA

mfejzo@mednet.ucla.edu

Supporting Information:

https://doi.org/10.1055/a-0830-1346

\section{ABSTRACT}

Objective Hyperemesis gravidarum, severe nausea and vomiting in pregnancy, occurs in up to $2 \%$ of pregnancies and leads to significant weight loss, dehydration, electrolyte imbalance, and ketonuria. It is associated with both maternal and fetal morbidity. Familial aggregation studies and twin studies suggest a genetic component. In a recent GWAS, we showed that placentation, appetite, and cachexia genes GDF15 and IGFBP7 are linked to hyperemesis gravidarum (HG). The purpose of this study is to determine whether GDF15 and IGFBP7 are upregulated in HG patients.

Methods We compared serum levels of GDF15 and IGFBP7 at 12 and 24 weeks' gestation in women hospitalized for HG, and two control groups, women with nausea and vomiting of pregnancy (NVP), and women with no NVP.

Results We show GDF15 and IGFBP7 serum levels are significantly increased in women with HG at 12 weeks' gestation. Serum levels of hCG are not significantly different between cases and controls. At 24 weeks gestation, when symptoms have largely resolved, there is no difference in GDF15 and IGFBP7 serum levels between cases and controls.

Conclusion This study supports GDF15 and IGFBP7 in the pathogenesis of $\mathrm{HG}$ and may be useful for prediction and diagnosis. The GDF15-GFRAL brainstem-activated pathway was recently identified and therapies to treat conditions of abnormal appetite are under intense investigation. Based on our findings, HG should be included.

\section{ZUSAMMENFASSUNG}

Hyperemesis gravidarum - Übelkeit und übermäßiges Erbrechen in der Schwangerschaft - tritt in bis zu $2 \%$ aller Schwangerschaften auf und führt zu erheblichem Gewichtsverlust, Austrocknung, Elektrolytentgleisungen und Ketonurie. Sie ist mit mütterlicher sowie fetaler Morbidität assoziiert. Familiäre Aggregationsstudien und Zwillingsstudien deuten auf eine genetische Komponente hin. In einer kürzlich publizierten, genomweiten Assoziationsstudie konnten wir zeigen, dass es einen Zusammenhang zwischen den Plazentations-, Appetitund Kachexie-Genen GDF-15 und IGFBP-7 und Hyperemesis 
gravidarum (HG) gibt. Ziel dieser Studie war es, zu prüfen, ob GDF-15 und IGFBP-7 in HG-Patientinnen hochreguliert sind. Methoden Wir verglichen die GDF-15- und IGFBP-7-Spiegel in SSW 12 und 24 von Frauen, die wegen HG ins Krankenhaus eingewiesen wurden, mit den GDF-15- und IGFBP7-Spiegeln von 2 Kontrollgruppen (Frauen mit normaler Übelkeit und Erbrechen in der Schwangerschaft und Frauen ohne Übelkeit und Erbrechen in der Schwangerschaft).

Ergebnisse Die GDF-15- und IGFBP-7-Spiegel von Frauen mit HG waren in SSW 12 signifikant erhöht. Dagegen unterschied sich der hCG-Serumspiegel nicht wesentlich zwischen Fällen und Kontrollen. In SSW 24 hatten sich die Symptome weitgehend gelegt, und es gab keine Unterschiede in den GDF15- und IGFBP-7-Spiegeln zwischen Fällen und Kontrollen.

Schlussfolgerung Diese Studie unterstützt die Hypothese, dass GDF-15 und IGFBP-7 eine Rolle bei der Pathogenese von HG spielen und dass sie bei der Vorhersage und Diagnose nützlich sein könnten. Der GDF-15-GFRAL-Hirnstamm-aktivierte Signalweg wurde vor Kurzem identifiziert, und es wird intensiv nach Therapien zur Behandlung von abnormen Essgelüsten geforscht. Vor dem Hintergrund unserer Ergebnisse sollte HG ebenfalls einbezogen werden.

\section{Introduction}

Nausea and vomiting of pregnancy (NVP) affects $50-90 \%$ of all pregnant women [1]. Hyperemesis gravidarum, the most severe form of NVP, occurs in $0.3-2 \%$ of pregnancies and leads to significant weight loss, dehydration, electrolyte imbalance, and ketonuria [2,3]. It accounts for 285000 hospital discharges in the US annually [4] and is associated with maternal morbidity such as Wernicke's encephalopathy, [5] renal and liver function abnormalities, [6,7] esophageal rupture, [8] and postpartum posttraumatic stress [9]. HG is associated with a 4-fold increased risk of adverse fetal outcome including low birth weight, intrauterine growth restriction, preterm delivery, fetal and neonatal death, and a 3-fold increased risk of neurodevelopmental delay in children $[10,11]$.

A variety of potential causative factors have been investigated, with the primary hypothesis being overproduction of the pregnancy hormone human chorionic gonadotropin (hCG) [2]. There has never been sufficient evidence to support the hCG theory and a recent large retrospective cohort study provides strong evidence against it [12]. Using an existing cohort with well-defined clinical criteria of intravenous fluid treatment for HG, we have successfully validated two candidate genes from our genome-wide association study (GWAS) that are highly likely to play a role in HG [13]. The two genes, GDF15 and IGFBP7, are both involved in placentation and feeding behavior; they are also associated with cachexia, a disease with similar symptoms to HG (nausea, vomiting, weight loss, anorexia, and muscle wasting) [14-19]. In addition, the GDF15 receptor GFRAL was recently identified and is localized in the brainstem where feeding behavior, nausea and vomiting are regulated [20]. The proteins encoded by the genes identified in our GWAS (GDF15, IGFBP7) are upregulated in early pregnancy and cause loss of appetite in animal models [14, 15, 17, 21 , 22]. Herein we analyze these candidate genes/proteins linked to $\mathrm{HG}$ to provide further evidence that they may ultimately serve as biomarkers for prediction, diagnosis, and identification of novel treatments.

\section{Materials and Methods}

\section{Serum cohort}

The Clinical Gravidity Association Trial and Evaluation (CGATE) programme was a prospective observational study. From November 2009 to December 2013, a total of 543 women were included in the CGATE programme. Pregnant women had to be at least 18 years old and diagnosed with an intact pregnancy no later than gestational week 13 . They were followed up prospectively with an optional visit at week 23 and a mandatory visit at the end of the pregnancy. The study was approved by the Ethics Committee of the medical faculty at Friedrich Alexander University of ErlangenNuremberg, Erlangen, Germany (\#4176).

For the present study, the women were excluded in the following hierarchical order: 14 women had to be excluded because of twin pregnancy; 11 women had to be excluded because they had fetuses with structural anomalies, 15 women had to be excluded because of abortion or stillbirth and 22 women had to be excluded because of insufficient documentation.

Women were asked to answer a structured questionnaire every 4 weeks beginning at study entry. These questionnaires included prospective questions about nausea, vomiting, co-medication, restless legs syndrome, depression and others. 389 of the remaining 481 women answered all questions about emesis from 12 to 24 weeks of gestation or had hospital stays because of hyperemesis gravidarum. Biomaterial was available for 354 of those. However, the commercial ELISA assay allows for 40 individual samples run in duplicate. To avoid inter-plate variation, the study was limited to 40 participants that included all 11 women with HG, a subset of 9 women with NVP, and 20 women reporting no NVP, and excluded the remaining 314 participants. Therefore, from the 354 patients, 11 patients (3\%) were hospitalized for HG and were selected for the HG subgroup, 65 (18\%) reported no nausea/vomiting at any time point and among these, 20 were randomly selected for the NO NVP subgroup. For the NVP subgroup, 278 (79\%) of women reported NVP. Among the women reporting NVP, 35 (13\%) of women reported nausea at all time points and vomiting during at least one time point, and 9 women were randomly selected from these 35 women to participate in the NVP subgroup. Thus the collective for analysis consists of 40 women (Supplementary Fig. S1). 
Blood samples for serum analysis were taken prospectively at the first visit (before 14 weeks) and second visit (20-24 weeks). Serum samples were collected in serum blood tubes (Sarstedt AG, Numbrecht, Germany). After centrifugation (2000 rpm, $10 \mathrm{~min}$ ) serum samples were stored at $-80^{\circ} \mathrm{C}$ until further use.

\section{Detection of GDF15, IGFBP7, and hCG protein levels in serum by ELISA}

GDF15 and IGFBP7 protein levels in serum were measured at 12 and 24 weeks gestation in 11 patients hospitalized for HG prior to 20 weeks, 9 patients reporting NVP, and 20 patients reporting no NVP prior to 24 weeks, using the human GDF-15 ELISA kit EA100484 (OriGene Technologies, Rockville, MD) and the Human IGFBP7 ELISA kit MBS288255 (MyBioSource, San Diego, CA). Detection of hCG protein levels in serum were measured at 12 weeks using the HUMAN HCG ELISA kit HC251F (Calbiotech Inc, El Cajon, CA). Serum samples were diluted 1:20 in sample diluent buffer and assayed according to the manufacturer's protocol. All assays were performed in duplicate. Absorbance was measured at a wavelength of $450 \mathrm{~nm}$ using a SpectraMax iD3 microplate reader from Molecular Devices LLC (Sunnyvale, CA).

\section{Statistical analysis of protein levels in serum}

To determine whether the mean serum levels of GDF15 at 12 weeks were significantly different between women hospitalized for HG, women with NVP, and women with no NVP, the Kruskal-Wallis test was used as the global test for the three groups HG, NVP and NO NVP. Because the Kruskal-Wallis test was significant, a Wilcoxon test between the separate groups was conducted.

To determine whether the mean serum levels of IGFBP7 at 12 weeks were significantly different between women hospitalized for HG, women with NVP, and women with no NVP, the Kruskal-Wallis test was used as the global test for the three groups HG, NVP and NO NVP. Because the Kruskal-Wallis test was significant, a Wilcoxon test between the separate groups was conducted.

To determine whether the mean serum levels of hCG at 12 weeks were significantly different between women hospitalized for HG, women with NVP, and women with no NVP, the
Kruskal-Wallis test was used as the global test for the three groups HG, NVP and NO NVP. Because the Kruskal-Wallis test was not significant, no further tests were performed.

To determine whether there is a significant difference between high and low serum levels of both GDF15 and IGFBP7 at 12 weeks gestation with respect to hospitalization for $\mathrm{HG}$ and no $\mathrm{HG}$, the Fisher's exact test was used to analyze the significance of the difference between categories of high and low serum values in the HG vs. no HG (combined NVP and NO NVP) groups.

To determine whether the mean serum levels of GDF15 at 24 weeks, when symptoms had lessened, remained significantly different between women hospitalized in previous weeks for $\mathrm{HG}$, women with NVP, and women with no NVP, the Kruskal-Wallis test was used as the global test for the three groups HG, NVP and NO NVP. Because the Kruskal-Wallis test was not significant, no further tests were performed.

To determine whether the mean serum levels of IGFBP7 at 24 weeks, when symptoms waned remained significantly different between women hospitalized in previous weeks for HG, women with NVP, and women with no NVP, the Kruskal-Wallis test was used as the global test for the three groups HG, NVP and NO NVP. Because the Kruskal-Wallis test was not significant, no further tests were performed.

Finally, a linear model was used to adjust for age, BMI, parity and fetal sex.

\section{Results}

\section{Cases hospitalized for HG have significantly higher serum levels of GDF15 and IGFBP7, but not hCG at 12 weeks gestation}

To determine whether serum levels of GDF15 and IGFBP7 are dysregulated in HG patients, we compared the levels of these biomarkers in pregnant women with HG. We analyzed serum concentrations of GDF15, IGFBP7, and hCG at 12 weeks gestation in 11 women hospitalized for $\mathrm{HG}$ compared to 9 women with normal nausea and vomiting of pregnancy (NVP), and 20 women with no NVP (NO NVP). Demographic characteristics are shown in

- Table 1 Demographic characteristics of cohort with serum. Continuous variables.

\begin{tabular}{|c|c|c|c|c|c|c|c|c|c|c|}
\hline Variable & Group & $N$ & Min & Q1 & Median & Mean & Q3 & Max & Sd & Missing \\
\hline \multirow[t]{4}{*}{ Maternal age } & $\mathrm{HG}$ & 11 & 20.0 & 25.5 & 29.0 & 28.8 & 31.5 & 38.0 & 4.8 & 0 \\
\hline & NVP & 9 & 26.0 & 29.0 & 31.0 & 30.2 & 32.0 & 33.0 & 2.2 & 0 \\
\hline & NO NVP & 20 & 22.0 & 29.8 & 34.0 & 33.4 & 37.2 & 42.0 & 5.2 & 0 \\
\hline & all & 40 & 20.0 & 28.0 & 31.0 & 31.4 & 34.2 & 42.0 & 4.9 & 0 \\
\hline \multirow{4}{*}{$\begin{array}{l}\text { BMI pre- } \\
\text { pregnancy }\end{array}$} & $\mathrm{HG}$ & 11 & 15.0 & 21.0 & 22.4 & 23.6 & 26.4 & 32.9 & 5.2 & 0 \\
\hline & NVP & 8 & 22.2 & 24.3 & 25.5 & 26.0 & 26.6 & 34.0 & 3.6 & 1 \\
\hline & NO NVP & 18 & 18.7 & 21.6 & 23.0 & 23.3 & 24.7 & 27.9 & 2.4 & 2 \\
\hline & all & 37 & 15.0 & 21.7 & 23.7 & 24.0 & 25.6 & 34.0 & 3.8 & 3 \\
\hline
\end{tabular}

$\mathrm{HG}$ = pregnant women hospitalized for $\mathrm{HG} \leq 20$ weeks gestation, $\mathrm{NVP}$ = pregnant women with normal nausea and vomiting of pregnancy,

$\mathrm{NO}=$ pregnant women with no NVP $\leq 24$ weeks gestation 
- Table 2 Demographic characteristics of cohort with serum. Categorical variables

\begin{tabular}{|c|c|c|c|c|c|c|c|c|c|}
\hline Variable & Levels & HG & $\%$ & NVP & $\%$ & NO NVP & $\%$ & $\mathrm{n}$ all & $\%$ all \\
\hline \multirow[t]{4}{*}{ Parity } & 0 & 8 & 72.7 & 6 & 66.7 & 9 & 45.0 & 23 & 57.5 \\
\hline & 1 & 3 & 27.3 & 2 & 22.2 & 9 & 45.0 & 14 & 35.0 \\
\hline & 2 & 0 & 0.0 & 1 & 11.1 & 2 & 10.0 & 3 & 7.5 \\
\hline & all & 11 & 100.0 & 9 & 100.0 & 20 & 100.0 & 40 & 100.0 \\
\hline \multirow[t]{3}{*}{ Fetal sex } & male & 0 & 0.0 & 3 & 33.3 & 13 & 68.4 & 16 & 41.0 \\
\hline & female & 11 & 100.0 & 6 & 66.7 & 6 & 31.6 & 23 & 59.0 \\
\hline & all & 11 & 100.0 & 9 & 100.0 & 19 & 100.0 & 39 & 100.0 \\
\hline \multirow[t]{4}{*}{ Education } & Junior high school & 5 & 45.5 & 6 & 75.0 & 10 & 50.0 & 21 & 53.9 \\
\hline & High school & 2 & 18.2 & 1 & 12.5 & 2 & 10.0 & 5 & 12.8 \\
\hline & College & 4 & 36.4 & 1 & 12.5 & 8 & 40.0 & 13 & 33.3 \\
\hline & all & 11 & 100.0 & 8 & 100.0 & 20 & 100.0 & 39 & 100.0 \\
\hline \multirow[t]{3}{*}{ Marital status } & not married/no relationship & 0 & 0.0 & 1 & 11.1 & 1 & 5.0 & 2 & 5.1 \\
\hline & married/relationship & 10 & 100.0 & 8 & 88.9 & 19 & 95.0 & 37 & 94.9 \\
\hline & all & 10 & 100.0 & 9 & 100.0 & 20 & 100.0 & 39 & 100.0 \\
\hline \multirow[t]{4}{*}{ Smoking } & never & 9 & 90.0 & 4 & 44.4 & 9 & 45.0 & 22 & 56.4 \\
\hline & before & 1 & 10.0 & 4 & 44.4 & 11 & 55.0 & 16 & 41.0 \\
\hline & at present & 0 & 0.0 & 1 & 11.1 & 0 & 0.0 & 1 & 2.6 \\
\hline & all & 10 & 100.0 & 9 & 100.0 & 20 & 100.0 & 39 & 100.0 \\
\hline
\end{tabular}

$H G$ = pregnant women hospitalized for $H G \leq 20$ weeks gestation, NVP = pregnant women with normal nausea and vomiting of pregnancy, $\mathrm{NO}=$ pregnant women with no NVP $\leq 24$ weeks gestation

- Tables 1 and 2. The mean serum concentrations of GDF15 in the three groups were $\mathrm{HG}=15.8$ (95\% Cl: 18.38, 13.23), $\mathrm{NVP}=10.45$ (95\% Cl: 13.02, 7.87), and NO NVP= 10.56 (95\% Cl: $11.93,9.2)$. The mean serum concentrations of IGFBP7 in the 3 groups were $\mathrm{HG}=71.08(95 \% \mathrm{Cl}: 87.57,54.58), \mathrm{NVP}=44.05$ (95\% Cl: 52.92, 35.18), NO NVP= 56.68 (95\% Cl: 68.85, 44.51).

The serum concentrations of GDF15 and IGFBP7 were significantly increased ( $p<0.001, p=0.002$, respectively) in women hospitalized for HG compared to women with NVP ( $\bullet$ Fig. 1 a and b). The serum concentrations of GDF15 were also significantly higher in patients with HG compared to women with no NVP $(p<0.001)$, but differences in serum levels of IGFBP7 did not reach significance $(p=0.123)$. There was no difference in serum GDF15 or IGFBP7 levels in patients with NVP compared to NO $\operatorname{NVP}(p=0.945, p=0.274$, respectively). Using the same samples, the serum concentrations of hCG at 12 weeks gestation were not significantly different between women with and without HG $(p=0.142)$. In summary, GDF15 is upregulated in pregnancies affected by HG compared to both control groups, IGFBP7 is upregulated in HG compared to NVP, and hCG is not upregulated in HG pregnancies compared to either control group. A linear model adjusted for age, BMI, parity, and fetal sex confirmed the abovementioned effects. GDF15 is upregulated in HG pregnancies compared to NO NVP on average $5.2 \mathrm{ng} / \mathrm{ml}$ (Supplementary Table S1) and IGFBP7 is upregulated in HG pregnancies compared to NO NVP on average $23.4 \mathrm{ng} / \mathrm{ml}$ (Supplementary Table S2).

\section{Elevated serum levels of GDF15 and IGFBP7 combined correlate with risk of $\mathrm{HG}$}

All 11 patients hospitalized for HG had serum levels of GDF15 $>10 \mathrm{ng} / \mathrm{ml}$ and 10/11 patients hospitalized for HG had serum levels of IGFBP7 > $60 \mathrm{ng} / \mathrm{ml}$ ( $\vee$ Fig. 2). We used these cutoff values to determine whether the combination of elevated levels of both GDF15 and IGFBP7 increased the risk of HG compared to no HG. We divided the serum values into high (GDF15 $>10 \mathrm{ng} / \mathrm{ml}$ and IGFBP7 $>60 \mathrm{ng} / \mathrm{ml}$ ) vs. low (GDF15 $\leq 10 \mathrm{ng} / \mathrm{ml}$ and IGFBP7 $\leq 60 \mathrm{ng} / \mathrm{ml}$ respectively) and compared them in patients with $\mathrm{HG}$ versus no HG (NVP and NO NVP combined). High serum levels of GDF15 and IGFBP7 were seen significantly more often in the HG group compared with the no HG group ( $p=0.000199)$.

\section{GDF15 and IGFBP7 serum levels are no longer significantly different at 24 weeks when HG symptoms subside}

To determine whether serum levels of GDF15 and IGFBP7 remain dysregulated after HG subsides, serum levels were also compared between the three groups at 24 weeks, when patients were no longer hospitalized for HG. Serum levels were no longer significantly different between cases and controls at 24 weeks gestation ( Fig. 3). 
Global test (Kruskal-Wallis), $\mathrm{p}<0.001$

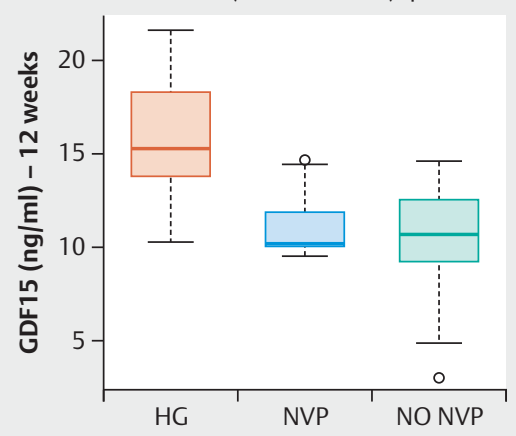

Due to significance of the Kruskal-Wallis test for GDF15, separate tests (Wilcoxon) between the groups are calculated:

- HG vs. NVP: $\mathrm{p}<0.001$

- HG vs. NO NVP: $p<0.001$

- NVP vs. NO NVP: $p=0.945$

Mean and $95 \%$ confidence limits for subgroups:

- HG: mean $=15.8,95 \% \mathrm{Cl}: 18.38,13.23$

- NVP: mean $=10.45,95 \% \mathrm{Cl}: 13.02,7.87$

- NO NVP: mean $=10.56,95 \% \mathrm{Cl}: 11.93$, 9.2

a

- Fig. 1 Serum levels of a GDF15 (ng/ml) and b IGFBP7 (ng/ml) and c hCG (mlU/ml) at 12 weeks gestation in women 1) hospitalized for HG (HG), 2) reporting NVP (NVP), and 3) reporting no NVP before 24 weeks gestation (NO NVP).
Global test (Kruskal-Wallis), $\mathrm{p}=0.028$

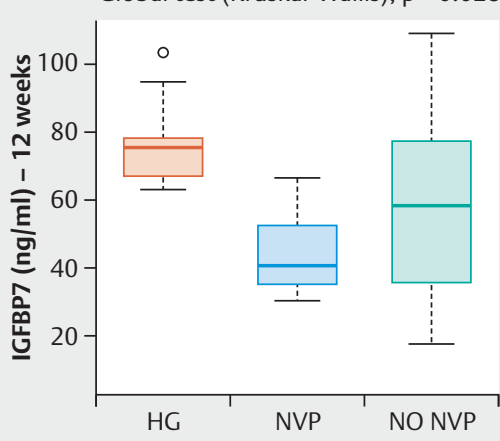

Due to significance of the Kruskal-Wallis test for IGFBP7, separate tests (Wilcoxon) between the groups are calculated:

- HG vs. NVP: $p=0.002$

- HG vs. NO NVP: $p=0.123$

- NVP vs. NO NVP: $p=0.274$

Mean and $95 \%$ confidence limits for IGFBP7 subgroups:

- HG: mean $=71.08,95 \% \mathrm{Cl}: 87.57,54.58$

NVP: mean $=44.05,95 \% \mathrm{Cl}: 52.92,35.18$

- NO NVP: mean $=56.68,95 \% \mathrm{Cl}: 68.85$, 44.51

b

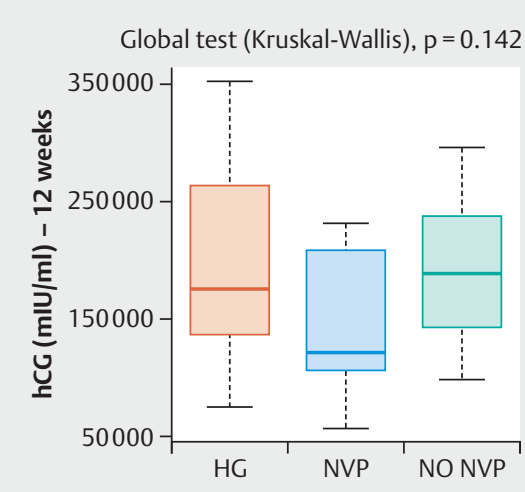

No significance in the Kruskal-Wallis test for hCG so no further tests are done.

\section{Discussion}

This is the first study linking altered serum levels of GDF15 and IGFBP7 to hyperemesis gravidarum and suggests a fascinating paradigm shift away from the hCG hypothesis. Herein we provide evidence of a role for GDF15 and IGFBP7 by showing they are dysregulated in $\mathrm{HG}$ pregnancies when symptoms peak, but not later in pregnancy when symptoms subside. Another recent study of 791 pregnant women showed increased serum GDF15 levels, but not hCG levels, were significantly associated with both second trimester vomiting and antiemetic use during pregnancy [23]. These results strongly support the recent GWAS findings implicating GDF15 (and IGFBP7) in the etiology and pathogenesis of HG [13]. Conversely, hCG, which was the leading hypothesis for the cause of HG, is not significantly different in cases compared to controls at 12 weeks gestation. This is in line with a recent large retrospective cohort study that found no evidence linking hCG levels to HG [12]. Additional supportive evidence of a role for GDF15 and IGFBP7 comes from previous studies showing they are upregulated in early pregnancy when HG occurs, play critical roles in placentation, decrease prior to miscarriage, and drive stress-induced feeding behavior and cachexia, a disease characterized by symptoms similar to HG [14-20,22, 24-26]. There is also evidence that GDF15 plays a role in both familial and recurrent cases of $\mathrm{HG}$, as genetic variants associated with increased GDF15 levels have been shown to segregate with disease in HG

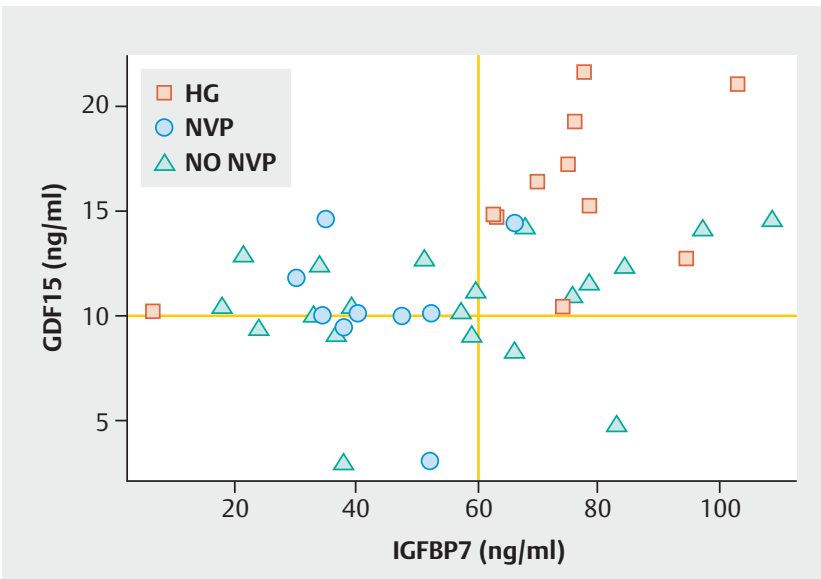

> Fig. 2 GDF15 (ng/ml) vs. IGFBP7 (ng/ml) scatterplot. Dividing serum values into high (GDF15 $>10 \mathrm{ng} / \mathrm{ml}$ and IGFBP7 $>60 \mathrm{ng} / \mathrm{ml}$ ) vs. low (GDF15 $\leq 10 \mathrm{ng} / \mathrm{ml}$ and IGFBP7 $\leq 60 \mathrm{ng} / \mathrm{ml}$ respectively), $\mathrm{p}$-value is 0.000199 , thus there is a significant difference for HG vs. no $\mathrm{HG}$ in the categories high and low serum values.

families and to be significantly associated with risk of recurrence [27]. While HG currently is a diagnosis of exclusion, the increased serum levels of GDF15 and IGFBP7 may be useful in diagnosing 


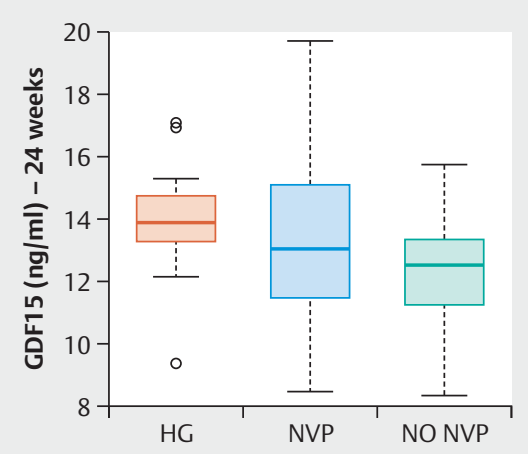

No significance in the Kruskal-Wallis test so no further tests are done.

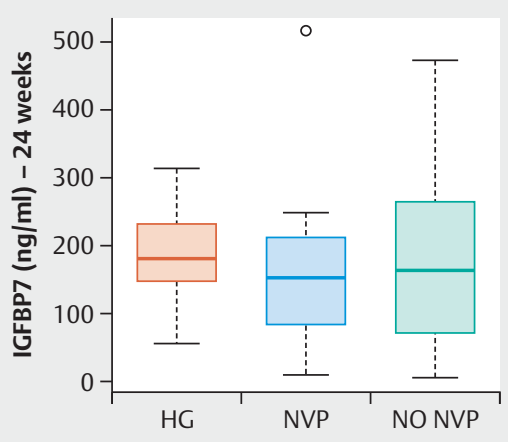

No significance in the Kruskal-Wallis test so no further tests are done.

b

- Fig. 3 Serum levels of a GDF15 (ng/ml) and b IGFBP7 (ng/ml) at 24 weeks gestation in women 1) hospitalized for HG (HG), 2) reporting NVP (NVP), and 3) reporting no NVP before 24 weeks gestation (NO NVP).

HG. The analysis of combined levels of both proteins resulted in a highly significant predictor for $\mathrm{HG}$, which suggests measuring the levels of both proteins may be an effective clinical test to predict and diagnose the disease. In the future, it may also be of interest to measure these proteins in other cases of extreme nausea and vomiting such as hydatidiform mole, which can also be associated with hyperemesis [28].

Admittedly there are limitations to the study. First and foremost, the study included only 11 patients hospitalized for HG. A significantly larger study comparing serum levels of HG patients and controls at various time points in gestation is now warranted to confirm the findings. In addition, while the association between serum levels of GDF15 and IGFBP7 support causality, proof of cause and effect requires more rigorous investigation.

Interestingly, while a $2.7 \mathrm{ng} / \mathrm{ml}$ increase in mean serum GDF15 levels $(5.4 \mathrm{ng} / \mathrm{ml}$ cachexia vs. $2.7 \mathrm{ng} / \mathrm{ml}$ controls) is suspected to initiate cancer cachexia, [18] herein we detected an increase in mean serum levels of over $5 \mathrm{ng} / \mathrm{ml}(15.8 \mathrm{ng} / \mathrm{ml} \mathrm{HG}$ vs. $10.5 \mathrm{ng} / \mathrm{ml}$ NVP) in patients hospitalized for HG compared to normal NVP. Serum concentrations of GDF15 in cancer patients with cachexia are significantly increased, even in the pre-cachetic state, and remain relatively steady thereafter [18]. Our findings suggest a similar upregulation of GDF15 production might be happening with HG and warrants further investigation. Levels of GDF15 (and IGFBP7) must be studied in early pregnancy to determine whether they can be used to predict an HG pregnancy. Furthermore, the brainstem-restricted receptor for GDF15, GFRAL, was recently identified and the pathway is actively being studied to identify novel therapeutic strategies for weight gain (and weight loss) [22]. Of particular clinical interest, inhibition of GDF15 restored appetite and weight gain in a mouse model of cancer cachexia [18]. If safe in pregnancy, this approach may be applicable to treating HG. Finally, the findings herein suggest an answer to an age-old paradox. HG can lead to prolonged dehydration and undernutrition, which can be detrimental to maternal and fetal health and can de- crease reproductive fitness. It has been hypothesized that NVP may be beneficial to avoid food that may be toxic to the fetus [29]. Another theory is that decreased appetite leads to nutrient deficiencies that signal increased growth of the placenta to maintain early pregnancy [30]. Whether either or both are true, the dual roles of GDF15 and IGFBP7 in placentation and feeding behavior may provide a molecular explanation for why HG still exists in nature.

\section{Conclusion}

In conclusion, GDF15 and IGFBP7 are not just genetically associated with $\mathrm{HG}$, but also, in this study serum levels are abnormally high in hospitalized patients. In the future, GDF15 and IGFBP7 levels may be used to predict, diagnose, and develop new treatments for HG.

\section{Acknowledgements}

This work has been presented, in part, at the International Colloquium on Hyperemesis Gravidarum, Windsor, England, October 5-6, 2017. This work was funded, in part, by the Hyperemesis Education and Research Foundation, and the Paul and Janis Plotkin Family Foundation. The authors thank the research participants for their contributions to this study, and Matthias Rübner, Hanna Hübner, Sonja Oeser and Silke Landrith for their management of the CGATE biobank.

\section{Conflict of Interest}

The authors declare that they have no conflict of interest. 


\section{References}

[1] Clark SM, Costantine MM, Hankins GD. Review of NVP and HG and Early Pharmacotherapeutic Intervention. Obstet Gynecol Int 2012; 2012 252676

[2] Verberg MF, Gillott DJ, Al-Fardan N et al. Hyperemesis gravidarum, a literature review. Hum Reprod Update 2005; 11: 527-539

[3] Kallen B. Hyperemesis during pregnancy and delivery outcome: a registry study. Eur J Obstet Gynecol Reprod Biol 1987; 26: 291-302

[4] Jiang HG, Elixhauser A, Nicholas J, Steiner C, Reyes C, Brierman AS. Care of Women in US Hospitals, 2000: HCUP Fact Book No. 3, No. 02-0044. Rockville, MD: Agency for Healthcare Research and Quality; 2002

[5] Chiossi G, Neri I, Cavazutti M et al. Hyperemesis gravidarum complicated by Wernicke's encephalopathy: background, case report and review of the literature. Obstet Gynecol Surv 2006; 61: 255-268

[6] Hill JB, Yost NP, Wendel GD jr. Acute renal failure in association with severe hyperemesis gravidarum. Obstet Gynecol 2002; 100: 1119-1121

[7] Adams RH, Gordon J, Combes B. Hyperemesis gravidarum. I. Evidence of hepatic dysfunction. Obstet Gynecol 1968; 31: 659-664

[8] Liang SG, Ooka F, Santo A et al. Pneumomediastinum following esophageal rupture associated with hyperemesis gravidarum. J Obstet Gynaecol Res 2002; 28: 172-175

[9] Christodoulou J, Mullin PM, Romero R et al. Posttraumatic Stress Symptoms (PTSS) following Hyperemesis Gravidarum (HG). J Matern Fetal Neonatal Med 2011; 24: 1307-1311

[10] Fejzo MS, Magtira A, Schoenberg FP et al. Antihistamines and other prognostic factors for adverse outcome in hyperemesis gravidarum. Eur J Obstet Gynecol Reprod Biol 2013; 170: 71-76

[11] Fejzo MS, Magtira A, Schoenberg FP et al. Neurodevelopmental delay in children exposed in utero to hyperemesis gravidarum. Eur J Obstet Gynecol Reprod Biol 2015; 189: 79-84

[12] Dypvik J, Pereira AL, Tanbo TG et al. Maternal human chorionic gonadotrophin concentrations in very early pregnancy and risk of hyperemesis gravidarum: A retrospective cohort study of 4372 pregnancies after in vitro fertilization. Eur J Obstet Gynecol Reprod Biol 2018; 221: 12-16

[13] Fejzo MS, Sazonova OV, Sathirapongsasuti F et al.; 23andMe Research Team. Placenta and appetite genes GDF15 and IGFBP7 are associated with hyperemesis gravidarum. Nat Commun 2018; 9: 1178

[14] Moore AG, Brown DA, Fairlie WD et al. The transforming growth factorss superfamily cytokine macrophage inhibitory cytokine- 1 is present in high concentrations in the serum of pregnant women. J Clin Endocrinol Metab 2000; 85: 4781-4788

[15] Liu ZK, Wang RC, Han BC et al. A Novel Role of IGFBP7 in Mouse Uterus: Regulating Uterine Receptivity through Th1/Th2 Lymphocyte Balance and Decidualization. PLoS One 2012; 7: e45224
[16] Tsai VW, Macia L, Johnen H et al. TGF-b Superfamily Cytokine MIC-1/ GDF15 Is a Physiological Appetite and Body Weight Regulator. PLoS One 2013; 8: e55174

[17] Bader R, Sarraf-Zadeh L, Peters M et al. The IGFBP7 homolog Imp-L2 promotes insulin signaling in distinct neurons of the Drosophila brain. J Cell Sci 2013; 126: 2571-2576

[18] Lerner L, Tao J, Liu Q et al. MAP3K11/GDF15 axis is a critical driver of cancer cachexia. J Cachexia Sarcopenia Muscle 2016; 7: 467-482

[19] Loncar G, Omersa D, Cvetinovic N et al. Emerging Biomarkers in Heart Failure and Cardiac Cachexia. Int J Mol Sci 2014; 15: 23878-23896

[20] Hsu JY, Crawley S, Chen M et al. Non-homeostatic body weight regulation through a brainstem-restricted receptor for GDF15. Nature 2017; 550: 255-259

[21] Marjono AB, Brown DA, Horton KE et al. Macrophage inhibitory cytokine-1 in gestational tissues and maternal serum in normal and pre-eclamptic pregnancy. Placenta 2003; 24: 100-106

[22] Xiong Y, Walker K, Min X et al. Long-acting MIC-1/GDF15 molecules to treat obesity: evidence from mice to monkeys. Sci Transl Med 2017; 9: pii: eaan8732

[23] Petry C], Ong KK, Burling KA et al. Associations of vomiting and antiemetic use in pregnancy with levels of circulating GDF15 early in the second trimester: A nested case-control study. Wellcome Open Res 2018; 3: 123

[24] Hsu LA, Wu S, Juang JJ et al. Growth Differentiation Factor 15 May Predict Mortality of Peripheral and Coronary Artery Diseases and Correlate with Their Risk Factors. Mediators Inflamm 2017; 2017: 9398401. doi:10.1155/2017/9398401

[25] Tong S, Marjono B, Brown DA et al. Serum concentrations of macrophage inhibitory cytokine 1 (MIC1) as a predictor of miscarriage. Lancet 2004; 363: 129-130

[26] Lerner L, Hayes TG, Tao $\mathrm{N}$ et al. Plasma growth differentiation factor 15 is associated with weight loss and mortality in cancer patients. J Cachexia Sarcopenia Muscle 2015; 6: 317-324

[27] Fejzo MS, Arzy D, Tian R et al. Evidence GDF15 Plays a Role in Familial and Recurrent Hyperemesis Gravidarum. Geburtsh Frauenheilk 2018; 78: 866-870

[28] Tempfer C, Horn LC, Ackermann S et al. Gestational and Non-gestational Trophoblastic Disease. Guideline of the DGGG, OEGGG and SGGG (S2k Level, AWMF Registry No. 032/049, December 2015). Geburtsh Frauenheilk 2016; 76: 134-144

[29] Sherman PW, Flaxman SM. Nausea and vomiting of pregnancy in an evolutionary perspective. Am J Obstet Gynecol 2002; 186 (5 Suppl. Understanding): S190-S197

[30] Huxley RR. Nausea and vomiting in early pregnancy: its role in placental development. Obstet Gynecol 2000; 95: 779-782 